\title{
The practice and thinking of promoting the balanced development of basic education with the UGSE platform
}

\author{
Ci Tang ${ }^{1, a}$ \\ ${ }^{1}$ Department of Computer Science, Chengdu Normal University, Chengdu, 610000 \\ ${ }^{a}$ email
}

Keywords : Education informatization, UGSE, Basic education balanced development

\begin{abstract}
Through constructing UGSE platform, overall to education informationization to promote the reform practice of balanced development of basic education. Established UGSE coordination to promote the mechanism of balanced development of basic education, to accelerate the process of education information construction, promote the basic education balanced development; The implementation of talent cultivation of higher normal colleges and scientific research and social service.
\end{abstract}

\section{Introduction}

To implement the "national medium and long-term education reform and development plan outline (2010-2020)", implement the strategy of sustainable development, in accordance with the "development of sichuan education informationization decade action plan (2011-2020) and the education department of sichuan province on deepening the reform of the education field comprehensive guidance (2014-2020)" requirements, through constructing education information technology as the leading, normal universities, government, schools and enterprises UGSE platform for broad participation, comprehensive to promote basic education balanced development of education informatization reform pilot work. Establish UGSE coordination to promote the mechanism of balanced development of basic education, to carry out the digital education resources construction and application, promote the fusion of information technology and education innovation, set up a batch of typical demonstration and education informationization application form the government, enterprises and schools to the pattern of education informatization, promote basic education in our province/balance, comprehensively improve the quality of education.

\section{The Status Quo}

The education informationization in promoting basic education balanced development of the role of play enough. In the education informatization infrastructure and capacity of system construction in our province has made some progress, the education informationization in the digital campus construction, teachers' information ability training effective ${ }^{[1]}$, but due to the region and level of education informatization development imbalance between intercollegiate, advanced information technology area and the gap between the school and laggard widening, the education informationization in promoting basic education balanced development of the role of play is not enough, is not conducive to sustainable development of education informatization.

Relative to the institutions of higher learning education informatization basic education obvious 
lag.Deeply integrated information technology and education teaching in universities has not yet been generally become school connotation development strategy, promoting teaching information idea obsolete, the conflicting policies from different departments, decentralized implementation issues, such as lack of propulsion system mechanism, relative to the institutions of higher learning education informatization basic education obvious lag.

The higher normal colleges and universities about promotion of basic education informatization, leading role is not strong.Research on elementary education of higher normal colleges is insufficient, the talent training mode, graduates are difficult to adapt to the need of basic education informatization rapid development, in the lead role in basic education informatization in normal colleges play enough.

The government, schools and the enterprises promote each other, the propulsion mechanism is not sound.Colleges and universities, primary and secondary schools, enterprises and so on in their own way to promote education informationization, government support, cooperation, mutual benefit, sharing resources between colleges collaborative propulsion system has not yet been established, and the mechanism of education informatization in normal colleges and universities for the lead to promote the system of balanced development of basic education mechanism has not yet formed, relevant successful mode has not been effective promotion and reference.

\section{Measures}

Full implementation of national education informatization development strategy, combining the reality of sichuan, promoting the construction of "3211" plan, solid in depends on the education informationization promoting regional balanced development of the education reform pilot work, innovation UGSE education informatization collaborative innovation model. Promoting regional balanced development of the education institutions and mechanisms, efforts to sichuan to speed up the construction of "four modernizations school" new pattern of education informatization development, contribute to promote the balanced development of basic education in our province.

Establish ZhengJiao QiXie long-term mechanism with innovation, to promote basic education balanced development.In the light of the sichuan education informationization decade development action plan (2011-2020) "proposed by programmatic goals, establish our province UGSE synergy propulsion mechanism, education informatization construction of government guidance, leading, enterprises to participate in the campus, the linkage of the social support mechanism, form the parties to the strong force of education informatization. One is to establish mutual benefit, mutual promotion of cooperative innovation mechanism. Establish a stable, standardized, balanced and efficient investment in education informatization and the performance evaluation mechanism, in accordance with the "government-led, multilateral financing, step by step input, balanced development" principle, to protect the investment of education informatization and high efficiency; The second is to build a support mechanism, sharing quality resources. To further improve the education in the area of weak schools in our province and the corresponding support informatization level; Three is to explore the new mechanism of balanced development of teachers. Give full play to teachers' resources of local famous quality demonstration radiation effect, in order to promote the balanced development of the education teachers equilibrium; Four is to explore the regional education information management and application system. Build infrastructure and education technology equipment specification management system, forming a set of management system innovation ${ }^{[2]}$.

Develop wisdom teaching scheme of the construction, exploration of basic education balanced development new pattern.To guide the school campus information environment for information 
architecture design, work out optimized campus implementation plan of information ecology, promote the school management mode, the change of teaching mode, life mode, enhance the core competitiveness of the school. Summarizing, refining and marketing experience and wisdom education development mode, to promote the education technology and the education teaching depth fusion, with technological changes lead the study way change, promote the education innovation, more research for regional education informationization development, the connotation of school development and brand construction ${ }^{[3]}$. Gradually formed a batch of the scheme of digital campus, and make the school in the information environment, information resources, information technology application, etc, become a pattern of similar schools in the city.

The innovative students training mode, improve students' education informatization practical application ability.Normal education informatization ability level is an important part of education informatization, is the basis of effective education informatization development, relying on "wisdom education alliance", as the research focus on the reform of higher normal colleges and universities pattern, focus on promoting higher normal education teaching and the depth of the primary and secondary school education informatization integration, training of qualified personnel in accordance with the requirements of the development of education informatization, improving the quality of personnel training ${ }^{[4]}$. Informatization in the promotion of basic education in normal colleges play in the development of bond and leading role. Through UGSE platform, to guide and improve the design and practice of students in normal colleges training mode, to promote students' education in normal colleges informationization courses and practical teaching system construction, improve the capacity to promote new technology enterprises merge with the depth of the higher education teaching. Let the students during the period of school will grow into a master the wisdom of teaching knowledge, methods and means of excellent teachers. Formation of pre-service training mode after integration, to achieve higher normal colleges and universities in the leading role in the process of promote the development of intellectual education.

Strengthen the teacher training, equilibrium to the teachers to promote the new mechanism of balanced development of education.Implementation of a variety of teaching methods and training methods, improve teachers' professional ability deep development, promote the balanced development of the weak school teacher ${ }^{[5]}$. In promoting the balanced development of the education process, teachers can grasp the innovation teaching theory and teaching method is the most critical. A number of ways to realize the remote teaching, online tutoring answering questions, such as online discussion and communication way to complete the participation subject introduction to the concentration of teacher training and subsequent training, make the teachers to learn and master all kinds of teaching theory, model and method. On this basis, establish the new mechanism of balanced development of teachers, give full play to teachers' resources of local famous quality demonstration radiation effect. To promote the balanced development of the education teachers equilibrium, thus to achieve a significant boost counterpart support the development of primary and secondary school teaching quality and students' ability to quality goals ${ }^{[6]}$.

Deepening the research on education informatization, comprehensively promote basic education balanced development.Promote transformation of the classroom teaching structure, and promote the balanced development of the students and improve the overall quality. To deepen cooperation with the education informatization research institutions, and constantly summarize basic education cross-over experiment research project in the process of classroom teaching experience, the comprehensive promotion, improve the classroom teaching efficiency, improve the teachers and students information literacy, promote the teachers and students comprehensive qualities and the improvement of professional quality. On the one hand, can be achieved through the depth of information technology and curriculum 
integration significantly enhance teaching quality and students' quality is, on the other hand can accumulate a batch of rich information-based teaching achievements, such as teaching resources, teaching case, the paper, from the school level, and ultimately form a set with the characteristics of sichuan province "by using modern education technology to improve compulsory education classroom teaching quality, promote the compulsory education balanced development" the informatization education solutions $^{[7]}$.

\section{Effective}

The higher normal school education informatization level and improved.Further improve the information infrastructure construction in normal colleges, formed to improve teachers' information technology teaching practice and application of normal training mode; In the course teaching system, teachers' information vocational skills training and assessment model of innovation and practice obtains the actual effect.

The more service informatization basic education in normal colleges.Initially formed by the higher normal colleges and universities as the leading service application and ability of primary and secondary school education informatization system. Technology supply output, teaching method, application mode, resource sharing service as the main form of the system, primary and secondary school to realize education informatization construction work of substantive changes.

Set up a long-term mechanism to promote the development of basic education balanced.Has set up a platform UGSE collaborative innovation, initially formed the service application and ability of the system, primary and secondary school education informatization technology supply output, teaching method, application mode, resource sharing service as the main form of the system, primary and secondary school to realize education informatization construction work of substantive changes. Formed a set of efforts to participate in the education informationization promoting basic education balanced development stable community.

Based on the informationization promoting education balanced/fruitful.Pilot information infrastructure of school to get further perfect, form a group of digital campus construction and wisdom education scheme to participate in the project pilot school classroom teaching quality improved significantly, after the implementation of most of the students achieve the project goals, established schools and weak advantages to narrow the gap between school students has obvious; To further narrow the gap between our province education informatization level in different areas of the, foundation and further improved the education balanced development support mechanism.

\section{Conclusion}

In short, through constructing UGSE collaborative innovation platform to promote basic education balanced development, is not only to carry out the informatization strategic national policies and education informatization, the necessary way to realize the modernization of education; Is to accelerate the process of education information construction in our province, to promote the necessary measures of balanced development of basic education. And the implementation of talent cultivation of higher normal colleges, scientific research and service the inevitable choice of social responsibility.

\section{References}

[1] K.L,Tang to create a rich digital learning environment for students - Australia's introduction of the 
"digital revolution" [J]. Journal of basic education reference, 2009 (10).

[2] Digital agenda in the European Union task force pushing $\mathrm{E}$ - Learning technology [DB/OL].http://www.elearningeuropa.info/en/download/file/fid/23401, 2014-2-28.

[3]U.S Department of Education, Office of Educational Technology, International Experiences with Educational Technology: Final Report[R]. Washington,D.C,2011:61-70.

[4] J.B.Zhang and X.Y,Zhang, International education informatization development report (2013-2014) [M] Beijing, Beijing normal university press, 2014:11.

[5] L,Chen,Y.H,Chen,X.D,Zheng and Z.C,Li. Education wisdom China led [J]. Journal of electrochemical education research, 2015, (4): 23-27.

[6] Y.B,Hu,X,Li and Y.J,Zhao. The school education informatization development present situation, visit the eu iTEC "classroom" future project director Dr Weill Ellis. China audio-visual education, 2016 (02): 121-125.

[7] Y,Wu and J.Y,Shu, Education informatization of regional education resources sharing leadership paper. Electrochemical education research, 2016 (01): 33-38 + 58. 